\title{
Law Due To The Transfer of Land Deed With Hands Down As Evidence
}

\author{
Eka Devi Febriyanti ${ }^{1}$, Moh. Abd Basith ${ }^{2}$ and Widhi Handoko ${ }^{3}$
}

Abstract. The purpose of this study were 1) To explain the legal consequences on the transition of land right under the deed of hand as evidence, 2) To explain the Deed Under Power of Hands For Evidence. This study, using normative juridical research and studied approach to legislation (the statute approach) which means that a problem will be seen from the legal aspect and to examine the legislation, then linked to the issues discussed, with material collected by conduct a literature study. Based on this research can be concluded 1)The legal consequences on the transition of land right under the deed of hand as evidence is not valid, because deed made and prepared by the parties to the contract in person, and not before a notary or other authorized officials. Deed under the hand strength can be absolute proof of the deed if legalized or notarized. Deed under hand notarized the deed generally made by the parties concerned on the agreement of both parties, while on his signature or thumbprint and executed before a notary. 2) Every deed under the hand required spiked with a letter dated statement from a notary or an officer appointed by the Act. Function deed under the hand that was authorized notary is certainty over the signature as that is party to sign it certainly was not anyone else.

Keywords: As a result of the Law; Transfer of Rights to Land; Hands Down Deed; Evidence.

\section{Introduction}

Soil is a natural resource for human life and is one of Indonesia's wealth that has a very important social function for the people of Indonesia to improve the prosperity and welfare. So that the designation should be established and governed by the laws. In the Constitution of the Republic of Indonesia of 1945 Article 33 paragraph (3) has stated that, earth and water and natural resources contained in it are controlled by the state and used for the greatest prosperity of the people.

The importance of soil for human life makes the need for land to grow in line with economic growth and development that require land as land. In the land of everyday life are often the disputes, disagreements and conflicts even to the court hearing. This arises because the ground has a very important role for the community, so that people trying to gain ground to justify all sorts of ways to get the land despite having to take land owned by others to transfer title to the land.

Therefore, it is composed of Act No. 5 of 1960 on Basic Regulation of Agrarian. One of the objectives of the Basic Agrarian Law (BAL) is to provide legal certainty with regard to the rights of the land held by the public. To achieve these objectives, the government held land registration, and expressly provided for in Article 19 paragraph (1) BAL stating that to ensure legal certainty, the Government held land registration

\footnotetext{
${ }^{1}$ Master of Notary Students, Faculty of Law UNISSULA Email: e.devi1602@gmail.com

2 Students of Master of Law, Faculty Of Law, Universitas Islam Sultan Agung email moh.basith18@gmail.com

${ }^{3}$ Notary/ PPAT at Semarang City.
} 
throughout the territory of the Republic of Indonesia in accordance with the provisions stipulated in Government Regulation. ${ }^{4}$

The provision is a necessity and an obligation for the government to regulate and administer the registration of land in all regions of Indonesia, which is then stipulated in Government Regulation No. 24 of 1997 on Land Registration, in this Regulation in Article 32 is set verification certificate as proof of entitlement. In order to ensure legal certainty by government held land registration which is recht-cadastral means aimed at ensuring legal certainty.

Deed made by or before a Notary / PPAT or other competent authority, based as authentic certificate according to the form and procedures stipulated in the Law on Notary ${ }^{5}$ This is in line with the opinion of Philip M. Hadjon, that the requirement of an authentic deed, namely: ${ }^{6}$

- In the form prescribed by law (raw form),

- Created by and in the presence of Public Officials.

PPAT deed is a deed is authentic, this was confirmed by Article 1 (1) and Article 3 (1) of Government Regulation No. 37 of 1998 on the Regulation of Land Deed Official Position. As an authentic deed, against PPAT deed of the provisions concerning the terms and procedures for the manufacture of an authentic deed. Authentic deed form determined by law, while officials may make it unavoidable that weighs the same shall be determined by the laws or regulations on par with the legislation. ${ }^{7}$

As an authentic deed, deed of PPAT as evidence that the strength of evidence that has degraded the strength of evidence can perfectly become such deed under hand. Degradation of evidence authentic certificate into evidence under the arm strength, and defects resulting in authentic juridical deed authentic deed can be canceled or null and void or non-existent, occurs if there is a violation of the provisions of the legislation are:

- Article 1869 of the Civil Code, which reads: A deed because it is not in power or not cakapnya employees referred to above or because of a defect in form, it can not be treated as an authentic deed, however, have the power as a deed under the hand if it is signed by the parties.

This article contains a provision, that a certificate does not have the power of authentic evidence and only has the power under the hand evidence in the case:

- Public officials are not authorized to make the deed;

- Public officials have been unable (incompetent) to make the deed;

- Defects in shape.

- Article 1320 of the Civil Code, which argued for a legal contract requirements must be met, namely:

- They agreed that bind;

- Skills make a perjanijan;

- A certain thing and

- Halal causes.

Terms of $a$ and $b$ is a requisite subjective because of the people or subjects that hold perijanjian and if the terms of subjective violated, the deed can be canceled, Whereas

${ }^{4}$ Boedi Harsono, 2008, Hukum Agraia Indonesia, Sejarah Pembentukan Undang-Undang Pokok Agraria, Isi dan Pelasanaannya, Djambatan, Jakarta, p. 471

${ }^{5}$ Ali Boediarto, 2005, Kompilasi Kaidah Hukum Putusan Mahkamah Agung, Hukum Acara Perdata Setengah Abad, Swa Justitia, Jakarta, p. 152

${ }^{6}$ Philipus M. Hadjon, 2000, Formulir Pendaftaran Tanah Bukan Akta Autentik. Surabaya, p 3.

${ }^{7}$ Herlien Budiono, 2007, Kumpulan Tulisan Hukum Perdata di Bidang Kenotariatan, Citra Aditya Bakti, Bandung, p. 59. 
Volume 6 Issue 2, June 2019

the terms $\mathrm{c}$ and $\mathrm{d}$ is the objective requirements for the contents of the agreement and if the objective requirements are violated, the deed null and void.

PPAT Deed serves as proof of the correct tool is already doing selling. Sale and purchase can still be proved by other means of proof. But in a land registration system in accordance with Government Regulation No. 24 of 1997 on Land Registration, registration and selling it can only be done with PPAT deed as proof. The person doing the selling without proven by PPAT deed will not be able to obtain a certificate, although sales of its purchasing lawful. ${ }^{8}$

Transfer of rights on land that is not carried out in the presence of PPAT is no sanction for the parties, but the parties will meet the practical difficulties of the assignee, will not be able to register transfer of rights so it will not get a certificate on his behalf. Therefore, the path that can be taken is to repeat the procedure right in front of PPAT transition. ${ }^{9}$

Based on the background of the problems mentioned above, then the problem can be formulated as follows: How can the legal consequences on the transition of land right certificates as evidence under the hand?, How the Power of Deeds Under Hand As Evidence?

\section{Research methods}

This study, using normative juridical research and studied approach to legislation (the statute approach) which means that a problem will be seen from the legal aspect and to examine the legislation, then linked to the issues discussed, with material collected by conduct a literature study.

Type of study in this research is descriptive research which is intended to gather information about the status or existing symptoms, the symptoms according to what their circumstances at the time of the study. ${ }^{10}$ This study intends to describe the data clearly on the object under study.

\section{Discussion}

\subsection{The legal consequences on the transition of land right under the deed of hand as evidence}

Viewed from the standpoint of the concept of ownership, it is for those who legally owns the rights to the land, whether registered or not registered may assign its rights to land. Diverting land rights, meaning the transfer of land rights owned by the other parties, with the removal in question, then the right will move. Rights in question, is a legal relationship which is attached as the competent authority or the power to take legal action. In the legal terminology the word "right" means the legal right, or basis for doing something legal action. ${ }^{11}$

In the civil law of evidence article / letter under Article 138,165,167 HIR / Article 164, 285, 305 and Article 1867-1894 Rbg-Civil Code, in principle in civil problems, evidence

\footnotetext{
${ }^{8}$ Effendi Perangin, 1994, Hukum Agraria Indonesia, Suatu Telaah Dari Sudut Pandang Praktisi Hukum, Raja Grafindo Persada, Jakarta, p. 15.

${ }^{9}$ J. Kartini Soedjendro, 2001, Perjanjian Peralihan Hak Atas Tanah Yang Berpotensi Konflik, Kanisius, Yogyakarta, p. 73

${ }^{10}$ Suharsimi Arikunto, 1990, Manajemen Penelitian, Rineka Cipta, Jakarta, p 309

${ }^{11}$ I.P.M. Ranuhandoko, 2000, Terminologi Hukum Inggris-Indonesia, Sinar Grafika, Jakarta, Cetakan Kedua, p. 487
} 
that a form of writing that is the preferred tool or appliance evidence evidence number one when compared with other evidence.

Related to the removal or transfer of land rights, the rights and views of the characteristics of the transition process rights, has elements of different laws, especially those related to the formal and material requirements, procedures, and mechanisms are largely determined by the nature or state of the subject and the object of rights. However, the main requirement is to be any evidence of land rights, namely proof of ownership in writing (formal) in the form "Certificate" (for land that has been registered), as well as "supporting evidence" (for land that has not been registered or not yet certified). The evidence in question can be: the deed of sale, grant, inheritance fatwa, a decree granting the right to land and buildings, and others. It is to provide certainty and legal power over land rights, land rights so that the transition is eligible legality according to the legislation in force.

The transition of land rights can not be done by the deed under the hand because since 1961 in particular on Article 1 Regulation of the Minister of Agrarian No. 11 of 1961 on Form Deed explaining that any transfer of land rights to be made by deed Land Deed Official (PPAT). Land Rights and Transitional conducted under the hand before the entry into force of Regulation No. 24 of 1997 can be used as evidence of the transition of land rights in accordance with the provisions of Article 24 in conjunction with explanation of Article 24 of the Old Right Proof PP 24 of 1997 on Land Registration. But if the Transition Land Rights is made after the entry into force of Regulation No. 24 of 1997 that the transition must be proved by PPAT Deed.

The legal consequences on the transition of land right under the deed of hand as evidence is not valid, becausedeed made and prepared by the parties to the contract in person, and not before a notary or other authorized officials.Deed under the hand strength can be absolute proof of the deed if legalized or notarized. Deed under hand notarized the deed generally made by the parties concerned on the agreement of both parties, while on his signature or thumbprint and executed before a notary.

\subsection{Under the Deed Strength Hand As Evidence}

Evidence in writing or letter is anything that contains signs reading understandable and contains a certain mind. Signs reading meant for example the Latin alphabet, Arabic alphabet, kanji and so forth. Thus everything that does not contain signs reading, or even though the load signs reading but can not understand, it is not included in the definition of evidence in writing or letter. ${ }^{12}$

Here is the strength of evidence deed distinguished into three kinds: ${ }^{13}$

- The strength of evidence of birth (a third party).

Referred to the strength of evidence born of a deed that is a strength of evidence based on the letter of the circumstances of birth, that a letter that looks like a deed, received / considered as a deed and treated as a deed, to the extent not proven the opposite.

- Formal proof strength

Defined as formal proof of the deed that is a strength of evidence based on whether or not the statement that the signing of the deed, that the signatory deed explained what was stated in the deed.

- The strength of evidence material

\footnotetext{
12 Moh. Taufik Makarao, 2009, Pokok-pokok Hukum Acara Perdata, Penerbit Rineka Cipta, Jakarta, p.99

${ }^{13}$ Ibid, p. 48
} 
Defined as material verification certificate that is a strength of evidence based on whether or not the contents of the statement signed in deed, that the legal events stated in the deed it really happened, so give certainty about the material deed.

Authentic act has the perfect evidence power (volledig bewijs) so that the certificate must be trusted by the judges, which shall be considered as true, as long the truth of authentic not be proofing. The deed has three (3) types of strength of evidence, namely:

- Formal evidentiary strength, which means proving between the parties that they have to explain what is written in the deed.

- The strength of evidence material, which means proving between the parties, that the true events about which the deed has occurred.

- The strength of evidence binding, which means that in addition to as proof of them there is also a third party in which the day, month, and year that the deed in question has been facing the public servants and to explain what is written in the deed.

Thus the authentic act has perfect power. Authentic deed truth can not be denied unless it can be proven otherwise, for example, no duplicity in the authentic deed. So for the judge would be very easy and have no hesitation in favor of the plaintiff which has been supported by the evidence is authentic. That the authentic act is an instrument which "binding" and "perfect".

\section{Closing}

\subsection{Conclusion}

- The legal consequences on the transition of land right under the deed of hand as evidence is not valid, because deed made and prepared by the parties to the contract in person, and not before a notary or other authorized officials.Deed under the hand strength can be absolute proof of the deed if legalized or notarized. Deed under hand notarized the deed generally made by the parties concerned on the agreement of both parties, while on his signature or thumbprint and executed before a notary.

- Every deed in under hand obliged spiked with a letter dated statement from a notary or an officer appointed by the Act. Function deed under the hand that was authorized notary is certainty over the signature as that is party to sign it certainly was not anyone else.

\subsection{Suggestion}

- In the process of implementation is impossible without involving the Land Deed Official, based on the provisions of a legal act performed before the Deed Official evidenced by a deed of land made by PPAT,

- Preparation of an authentic deed assist judges in giving its decision as an act which natariel, it is neutral and not take sides, and a notary can be a witness if needed. The deed made in under hand frequent emphasis on those who really need them, there is no balance due to be made by the parties themselves. We recommend that every agreement made by and in the presence of a Notary.

\section{Bibliography}


[1] Ali Boediarto, 2005, Kompilasi Kaidah Hukum Putusan Mahkamah Agung, Hukum Acara Perdata Setengah Abad, Swa Justitia, Jakarta

[2] Boedi Harsono, 2008, Hukum Agraia Indonesia, Sejarah Pembentukan UndangUndang Pokok Agraria, Isi dan Pelasanaannya, Djambatan, Jakarta

[3] Effendi Perangin, 1994, Hukum Agraria Indonesia, Suatu Telaah Dari Sudut Pandang Praktisi Hukum, Raja Grafindo Persada, Jakarta

[4] Herlien Budiono, 2007, Kumpulan Tulisan Hukum Perdata di Bidang Kenotariatan, Citra Aditya Bakti, Bandung

[5] I.P.M. Ranuhandoko, 2000, Terminologi Hukum Inggris-Indonesia, Sinar Grafika, Jakarta, Cetakan Kedua

[6] J. Kartini Soedjendro, 2001, Perjanjian Peralihan Hak Atas Tanah Yang Berpotensi Konflik, Kanisius, Yogyakarta

[7] Moh. Taufik Makarao, 2009, Pokok-pokok Hukum Acara Perdata, Penerbit Rineka Cipta, Jakarta

[8] Philipus M. Hadjon, 2000, Formulir Pendaftaran Tanah Bukan Akta Autentik. Surabaya

[9] Suharsimi Arikunto, 1990, Manajemen Penelitian, Rineka Cipta, Jakarta 